\author{
Asian Journal of \\ Medical and Biological Research \\ ISSN 2411-4472 (Print) 2412-5571 (Online) \\ www.ebupress.com/journal/ajmbr
}

\title{
Article \\ The perception of sacred trees as proponent of water spring in Malang Regency East Java, Indonesia
}

\author{
Jati Batoro*, Luchman Hakim and Brian Rahardi \\ Biology Department, Faculty of Mathematics and Natural Sciences, Universitas Brawijaya, Jl. Veteran Malang \\ 65145, East Java, Indonesia \\ *Corresponding author: Jati Batoro, Biology Department, Faculty of Mathematics and Natural Sciences, \\ Universitas Brawijaya, Jl. Veteran Malang 65145, East Java, Indonesia. Telp-fax: +62-341-575841; E-mail: \\ jati_batoro@yahoo.co.id; j_batoro@ub.ac.id
}

Received: 31 July 2020/Accepted: 26 August 2020/ Published: 30 September 2020

\begin{abstract}
A spring is a place where water comes out of the ground seepage, seeps into the soil, then flows through cracks, gaps or natural tracts. Springs (sumber, tuk, umbulan, belik) are used to extract water by local people. This study was aimed at uncovering the knowledge about the types of sacred trees which supported the traditional conservation for water spring in Malang regency. The survey was carried out directly by taking three specimens in the spring environment. Interviews were conducted in person, in-depth, semi-structurally to the local community and tribe leaders. This study contained also the description of the diversity of sacred tree species which supported water spring in Malang Regency, East Java. The results of the study recorded 41 types of 27 genera and 20 families. The diversity of sacred tree species that are believed to be sacred include: ringin (Ficus benyamina), lo (Ficus glomerata), serut (Streblus asper), ipik-ipik (Ficus procera), ilat-ilat (Ficus callosa), bendo (Artocarpus elastica), jambu klampok watu (Syzygium littorale), aren (Arenga pinnata), gayam (Inocarpus fagifer), cangkring (Erythrina fusca). The types of water spring supporter are: bambu ori (Bambusa blumeana), bambu betung (Dendrocalamus asper), bambu apus (Gigantochloa apus), and of the familia Apocynaceae (Ervatamia sphaerocarpa), kecrutan (Spathodea campanulata), waru gunung (Hibiscus similis) etc. The existence of those meaningful trees is a symbol of the existence of a spring and the start of sustainable culture and customs in Malang Raya. Thus, petren needs to get the recognition as a longer, traditional conservation model from the government especially from the local government in a form of village regulation. Preserving the springs and environment is a local wisdom of the people of Malang regency, in an effort to preserve traditional conservation and harmony with the lives of other organisms.
\end{abstract}

Keywords: water spring; Malang Regency; sacred; traditional conservation

\section{Introduction}

Malang Raya is bordered by the Regencies of Blitar, Pasuruan, Lumajang and Indonesian Ocean. Malang Raya area covers Malang regency, Malang city, and Batu city with its cool air that makes it very suitable for settlement and plants cultivation. The fact that its area forms a basin as it is located among Bromo, Tengger, Kawi and Arjuno mountains makes it rich in springs. East Java has a number of indigenous people (tribes) including Javanese, Madurese, Tengger, Samin, Osing, and ethnic Chinese so that it is rich in cultural diversity, customs, language, religion, beliefs, and rituals. Therefore, the existence of customary rituals and beliefs is a form of creativity, innitiative and work by utilizing biodiversity in the environment. People's understanding of nature is connected with its function in their belief system and religion (Wickramasinghe, 2003).

The water from the spring comes out to the surface of the ground as a result of the aquifer because the surface of the ground is higher than the place where the water comes out. The water from the spring then flows or pops out from under the ground to the surface. The water cycle or hydrological cycle is a steady natural water cycle from the atmosphere to the earth or vice versa. However, the influence of vegetation is closely related to seepage, 
storage of water content at the soil surface. In general, the place or position of a water spring is in a basin or valley, along a river that flows between trees, bushes, certain herbs, and through rooting.

Natural resources in the form of springs are closely related to people's lives, even now they have been developed by the Regional Water Company (PDAM), utilized by the community, factories, and housing. The sacred water springs in local communities called petren (Punden) are the areas to put offerings, pray and seek blessings to allow families, all individuals in the community and the environment undisturbed. Therefore, its existence becomes very beneficial, important and vital. Various types of local trees that support traditional conservation are long-lived and shady, known as the source of the water springs. Local communities preserve the springs in the form of sacred or Punden areas (Petren). Petren is the place of ancestral spirit, village guard or the core of the village that is the place for ritual ceremony and burning of Petra (bespa) (Batoro, 2017; Batoro et al., 2019).

Backer \& Bakhuizen Van Der Brink (1986) explain that in Java, Ficus family has more than 120 species and is always green (evergreen) that has an important ecological function in tropical rainforest environment, in which the fruits serve as food for birds, mammals and insects. The family of Ficus spp. belongs to the Moraceae family with its long taproot penetrating the ground. It is equipped with breathing roots and the leaves have bags of water that make it cool being underneath (Batoro, 2019). Diversity of Ficus genus which includes Bodhi tree (Ficus religiosa), ringin (Ficus benyamina), ipik-ipik (Ficus procera), ilat-ilat (Ficus callosa), lo (Ficus glomerata) affects the culture of the people in association with their religious beliefs. The Ringin tree (Ficus Benyamina) can be hundreds of years old with a diameter of 1-6 meters with its taproot that has branches underground and it has dense breathing root that creates creepy and unique character. The sacred place in the Tengger tribe is called danyang banyu which is a punden that is closely related to water spring and is very important for natural and cultural conservation. That area is used to prepare traditional events such as Suro month, Jumat Legi (market day), Kasada (Tengger tribe), and marriage events. Sacred area is an important means for cultural expression and transmission, which requires recognition and support for the rights of their traditional caretakers and local communities (Samakov and Berkes, 2017). The plants have several functions such as preventing soil erosion, landslide and conserving the spring and water (Siswanto and Batoro, 2019).

\section{Materials and Methods}

The research was conducted in the spring and the sacred area at Malang Regency area in 2019 (Figure 1). Sacred tree species and supporting trees are measured at a distance of 1-2 meters from the center of the spring. The research was conducted in eleven districts including Pakis, Poncokusumo, Tumpang, Turen, Gondang Legi, Singosari, Lawang, Dau, Karang Ploso, Pakisaji and Wagir. The research was done using survey method, openended, semi-structural and in-depth interview (Cotton, 1996; Sheil et al., 2004; Hoffman and Gallaher, 2007). There were 25 informants chosen based on considerations of knowledge, willingness, gender factors, position (head of the village, community leader, local people and local guide). The diverse species of sacred trees and water spring supporting-trees were collected, characterized, determined, and stored in Universitas Brawijaya Herbarium (HBUR) (Backer and Bakhuizen van den Brink, 1968; Harris and Harris, 2003).

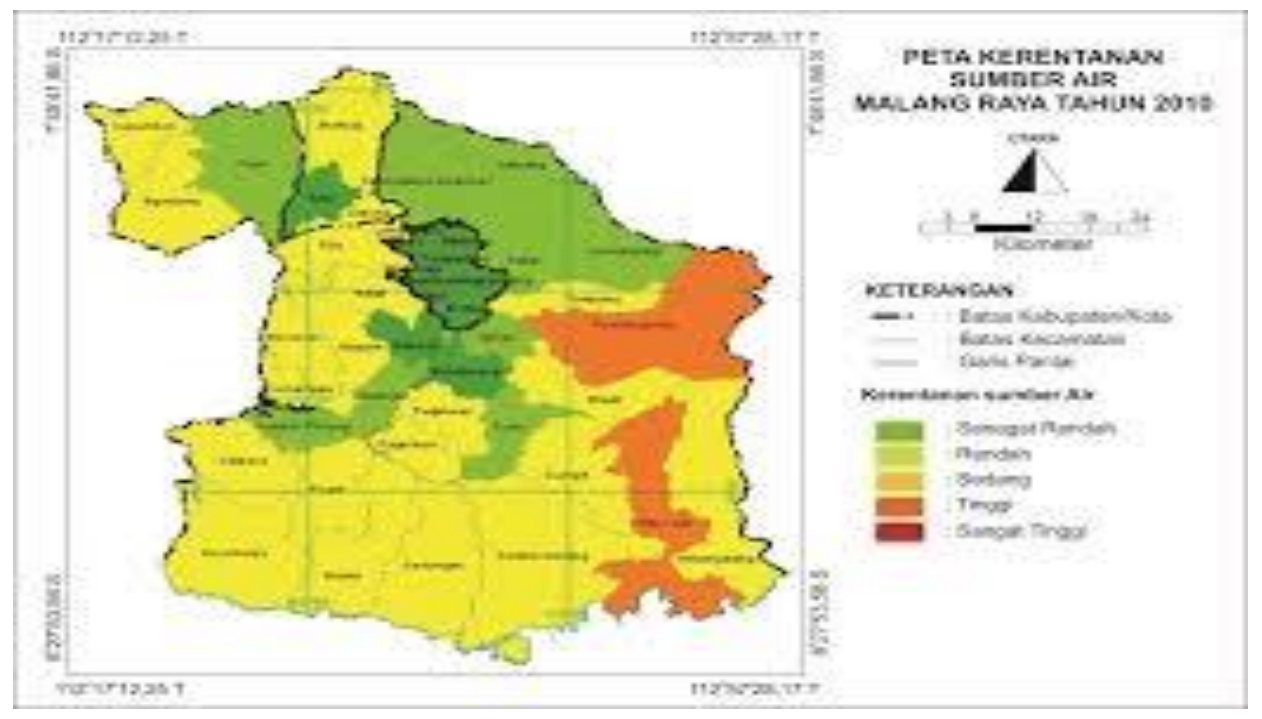

Figure 1. Map of Malang Raya, East Java. 


\section{Results and Discussion}

The petren area in Malang regency with its spring turned out to have a very important role namely: a. preserving traditional knowledge; b. possessing high ecological conservational value; c. preserving cultural diversity, d. possessing local religious values and beliefs; e. preserving species, genetic of local plants; f. serving as the construction area of the Regional Water Company (PDAM); g. becoming the area for factory and housing development; $h$. supporting the irrigation for cultivating plants, and i. serving as the proponent of education and ecotourism. Perceptions, conceptions, information, and changes about the meaning of petren need to get attention in supporting traditional conservation. This traditional conservation in the form of springs and their environment or petren has been maintained by local communities themselves and has a more long-term and sustinable meaning (Figure 2). The community has tried and been able to preserve these springs through the preservation of various species of Moraceae family trees such as lo (Ficus glomerata), ringin (Ficus benyamina), ilat-ilat (Ficus callosa), ipik-ipik (Ficus procera) and other various types of supporting trees such as bamboo species. Local people have been able to choose and determine the type of tree that has long life and a sacred meaning which is used as an effort to preserve water springs.
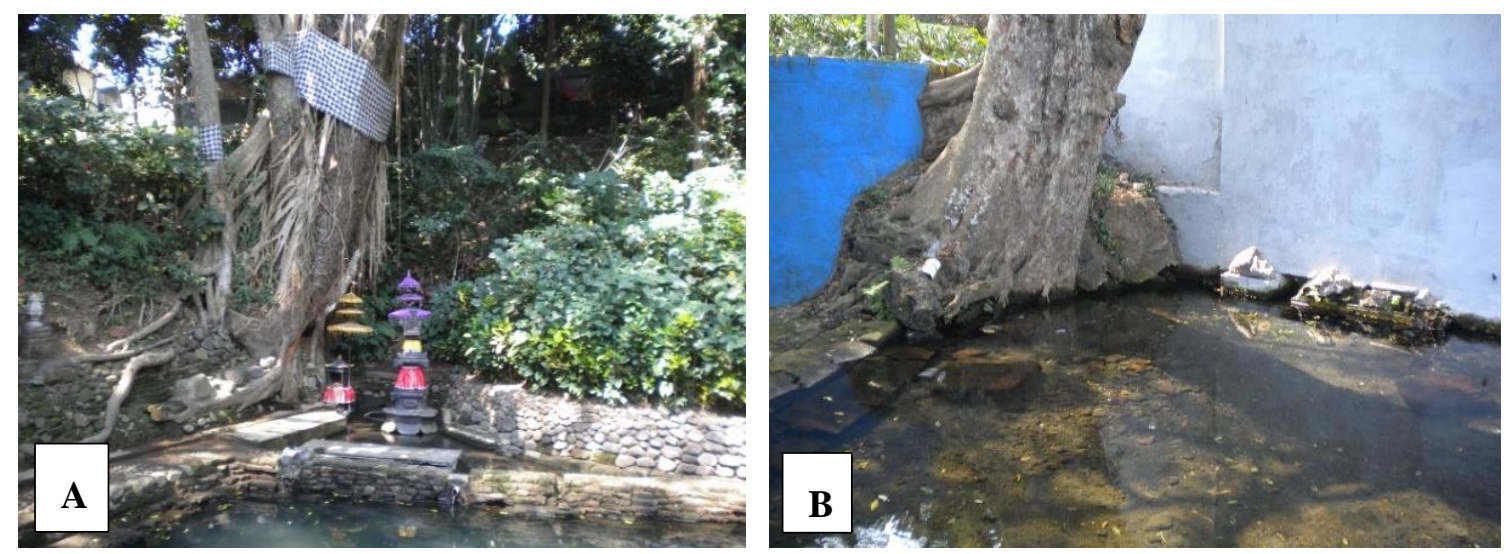

Figure 2. A. Sumber Watu Gede Petren in Singosari District. B. Wendit water spring under lo tree (Ficus glomerata).

The tree species that are considered sacred are ringin (Ficus benyamina), ipik-ipik (Ficus procera). Some types of Moraceae are believed to be able to preserve the springs and become objects of worship by the community and the shamans. The presence of sacred tree species in springs is also related to the state of the land and the heigth/ altitude of the location. Some petren with water spring have been used by the surrounding community, even as tourist destinations, swimming sites, and the place to hold traditional rituals since ancient times until now. There are various types of trees in petren that are believed to be sacred, including klampok (Syzygium densiflora), ringin (Ficus benyamina), bendo (Artocarpus elasticus), aren (Areca pinanga) and gayam (Inocarpus fagifer). The sacred tree and its proponent tree apparently have a meaning as a source of water conservation. This water spring is generally used as drinking water, for washing, irrigating rice fields, for traditional rituals and some springs have been managed by the Regional Water Company (PDAM), housing, and companies like Kebon Agung sugar factory which utilizes Soka Spring. Other examples of springs that are utilized by PDAM are Wendit, Karangploso, Karangan, Sumber Pitu Springs, etc. According to the local community, the use of springs managed by PDAM is more practical and efficient; as a result, some of the smaller natural springs disappeared, or even closed.

The springs in Malang Regency include the ones in the districts of : Pakis (3), Poncokusumo (4), Tumpang (4), Turen (2), Gondang legi (3 ), Singosari (3), Lawang (4), Dau (2), Karang Ploso (4), Pakisaji (1), Wagir (3). The springs that are located at the lowest location are: Sumber Sira that is located in Gondang Legi district with an altitude of 317 masl., S. 08.16494 dan E. 112.59399, Sumber Danyang Perhutani in Poncokusumo district with an altitude of 1240 masl; S. 07.99492; E. 112. 61290. Meanwhile, the spring that is located at the highest location is Sumber Brantas in Bumiaji district with an altitude of 1592 masl., S. 07.93509 and E. 112.61298 from which Brantas river originated. Wickramasinghe 2003 reported Sri Pada, the sacred foodprint is on the summit of this mountain range, and has more than 2500 years of history. The traditional petren or punden conservation model has preserved and sustainable conservation value (Batoro et al., 2019).

The species of sacred trees and trees supporting spring water in Malang Regency include 41 species from 27 genera and 20 families (Table 1). Sacred land is sanctuaries as well as agricultural estates and meadows, groves 
and woods, fallow land and land used for specific rituals in the context of a cult (Horster, 2010). The trees that are considered sacred are ringin (Ficus benyamina), lo (Ficus glomerata), serut (Streblus asper), ipik-ipik (Ficus procera), ilat-ilat (Ficus callosa), bendo (Artocarpus elastica), klampok (Syzygium densiflora), gayam (Inocarpus fagifer), aren (Arenga pinnata), cangkring (Erythrina fusca) etc. Bamboos (pring) which have an important role in helping to preserve springs are bambu ori (Bambusa blumeana), bambu betung (Dendrocalamus asper), bambu apus (Gigantochloa apus), pring jajang (Gigantochloa atter), pring ampel (Bambusa vulgaris). Therefore, it is necessary to conserve bamboo species around the spring for its preservation.

The local people have apparently been able to preserve and determine the type of long-lived tree, which is a meaningful tree species and is used as a traditional environment conservation. Environmental condition and characteristics of springs, diverse community knowledge and local cultures will influence the management of springs (Sudarmadji, 2016). The existence of the ritual indicates the fact of life that is applied in a culture and custom. Selected and natural tree species indicate a sign of the start of the existence of cultural customs, as a form of attributes and tribal symbols for the next generation. The preservation of springs are very beneficial for the lives of the surrounding community and the general public. Utilization of biodiversity for traditional rituals and springs as a conservation area by the community is actually an unintentional proof. Plants with their correct nomenclature were arranged by vernacular name, scientific name, family name, and habitus, status.

Table 1. The diversity of sacred tree species and supporting trees for water spring in Malang Regency, East Java.

\begin{tabular}{|c|c|c|c|c|}
\hline $\begin{array}{l}\text { SL. } \\
\text { No. }\end{array}$ & Local name & Scientific name & Familia & $\begin{array}{l}\text { Habitus, status, water } \\
\text { source supporters }\end{array}$ \\
\hline 1 & Mangga & Mangifera indica $\mathrm{L}$. & Anacardiaceae & Tree, support \\
\hline 2 & Gembirit & Ervatamia sphaerocarpa (Bl.) Burk. & Apocynaceae & Tree, support \\
\hline 3 & Rotan & Calamus sp. & Arecaceae & Tree, liana, support \\
\hline 4 & Kecrutan & Spathodea campanulate Beauv. & Bignoniaceae & Tree, support \\
\hline 5 & Randu alas & Gossampinus malabarica (DC.) Merr. & Bombaceae & Tree, support \\
\hline 6 & Paku pohon & Cyathea contaminans Wall. ex Hook. & Cyatheaceae & Tree, support \\
\hline 7 & Asem & Tamarindus indica $\mathrm{L}$. & Fabaceae & Tree, support \\
\hline 8 & Cangkring & Erythrina fusca Lour. & Fabaceae & Tree, sacred, support \\
\hline 9 & Dadap & Erythrina variegata $\mathrm{L}$ & Fabaceae & Tree, support \\
\hline 10 & Gayam & Inocarpus fagiferus (Parkinson) Fosb. & Fabaceae & Tree, sacred, support \\
\hline 11 & Trembesi & Samaea saman (Jacq.) Merr. & Fabaceae & Tree, support \\
\hline 12 & Pasang & Lithocarpus javensis $\mathrm{Bl}$. & Fagaceae & Tree, support \\
\hline 13 & Rukam & Flacourtia rukam Z.\&M. & Flacourtiaceae & Tree, support \\
\hline 14 & Danglu & Engelhardia spicata Lech.ex Bl. & Juglandaceae & Tree, support \\
\hline 15 & Waru gunung & Hibiscus similis L. & Malvaceae & Tree, support \\
\hline 16 & Mahoni & Swietenia macrophylla King. & Meliaceae & Tree, support \\
\hline 17 & Suren & Toona sureni (B1.) Merr. & Meliaceae & Tree, support \\
\hline 18 & Bendo & Artocarpus elasticus & Moraceae & Tree, sacred, support \\
\hline 19 & Bulu/preh & Ficus pilosa Reinw ex Bl. & Moraceae & Tree, sacred, support \\
\hline 20 & Ilat-ilat & Ficus callosa Wild. & Moraceae & Tree, sacred, support \\
\hline 21 & Ipik-ipik & Ficus procera Auct. non Salisb. & Moraceae & Tree, sacred, support \\
\hline 22 & Lo/gondang & Ficus glomerata Roxb. & Moraceae & Tree, sacred, support \\
\hline 23 & Luwing & Ficus hispida L.f. & Moraceae & Tree, support \\
\hline 24 & Ringin & Ficus benyamina L. & Moraceae & Tree, sacred, support \\
\hline 25 & Serut & Streblus asper Lour. & Moraceae & Tree, sacred, support \\
\hline 26 & Kadut & Syzygium sp. & Myrtaceae & Tree, sacred, support \\
\hline 27 & Klampok & Syzygium klampok (Mig.) Amsh. & Myrtaceae & Tree, sacred, support \\
\hline 28 & Poo & Melaleuca Leucadendron (L.) L. & Myrtaceae & Tree, support \\
\hline 29 & Salam & Syzygium polyanthum (Wight) Walp. & Myrtaceae & Tree, support \\
\hline 30 & Pinus & Pinus merkusii Jungh. \& De Vriese. & Pinaceae & Tree, support \\
\hline 31 & Tinggan & Pittosporum ferrugineum & Pittoporaceae & Tree, support \\
\hline 32 & Aren & Arenga pinnata (Wurmb) Merr. & Arecaceae & Tree, sacred, support \\
\hline 33 & Pring ampel & Bambusa vulgaris Schrad. & Poaceae & Tree, support \\
\hline 34 & Pring apus & Gigantochloa apus (Bl. ex Schult. f.) Kurz. & Poaceae & Tree, support \\
\hline 35 & Pring jajang & Gigantochloa atter (Hassk.) Kurz ex Munro & Poaceae & Tree, support \\
\hline
\end{tabular}




\begin{tabular}{|c|l|l|l|l|}
\hline 36 & Pring ori & Bambusa blumeana Bl.ex Schult. f. & Poaceae & Tree, support \\
\hline 37 & Pring petung & $\begin{array}{l}\text { Dendrocalamus atter (Schult.f.) Backer ex } \\
\text { Heyne }\end{array}$ & Poaceae & Tree, support \\
\hline 38 & Soka & Ixora javanica (Bl.) DC. & Rubiaceae & Tree, support \\
\hline 39 & Kemuning & Muraya paniculate (L.) Jack. & Rutaceae & Tree, support \\
\hline 40 & Matoa & Pometia pinnata J.R. \& g.Forst. & Sapindaceae & Tree, support \\
\hline 41 & Genitri & Elaeocarpus sphaericus (Gaertn.) K.Schum. & Tiliaceae & Tree, support \\
\hline 42 & Jati & Tectona grandis L.f. & Verbenaceae & Tree, support \\
\hline
\end{tabular}

\subsection{The pressures received by sacred area (petren)}

The pressures received by the sacred springs in Malang Raya are: a) The fading of local beliefs and wisdom about their existence because they are considered unscientific; b) the pressure on the region for the benefits of agricultural business by replacing local plants with cultivated plants, so that the volume of the water flowing from the springs becomes smaller; c) the development of housing areas, monopoly of springs by PDAM, so that small springs around the community are not used, or even closed; d) The construction of buildings, toll roads that pass through water springs and, e) the improvement of education of the locals. Such recognition can be carried out in culturally appropriate ways, enhancing biocultural conservation and affirming the rights of their traditional caretakers (Samakov \& Berkes, 2017). The existence of biodiversity as a water reservoir at a spring does not receive serious attention, so it needs the support of relevant parties and the government. In reality, water supply in Malang city still depends on the existence of spings from Malang Regency.

\section{Conclusions}

Water springs turn out to have an important role in preserving traditional knowledge, as a local conservation, in preserving traditional culture, religion and beliefs, preserving species, genetics and being utilized by education and ecotourism. The environment of the water springs in Malang regency consists of sacred tree area (petren) and in several cases, their sanctity has faded away. Petren is located in the TN-BTS area, Perhutani, and private or village-owned land.

There are a total of 33 springs in Malang regency. Sacred trees of the Moraceae family are: ringin (Ficus benyamina), ipik-ipik (Ficus procera), ilat-ilat (Ficus callosa), lo (Ficus glomerata), bendo (Artocarpus elasticus), serut (Streblus asper); familia Fabaceae, Arecaceae, aren (Arenga pinnata), and Myrtaceae, jambu klampok (Syzygium densiflora) and the bamboo type of Poaceae (barongan). The tree species supporting water springs in Malang regency include Moraceae (8 types), Fabaceae (4 types), Poaceae (3 types), Meliaceae (2 types), and other families (1 type),

Punden (petren) is a model of traditional conservation areas preserved to support springs, culture, and natural resources. Conservation is done on selected tree species and those trees are made sacred to conserve water springs. There is a need for the petren to get recognition from the government, relevant agencies, especially in the form of village regulation (PERDES), even though the local people have their own customary rules.

\section{Acknowledgements}

This research was funded by DPP/SPP of 2019 in the Faculty of Mathematics and Natural Sciences of Universitas Brawijaya. Gratitude is given to the Dean of the faculty, Prof. Adi Susilo and the Head of Biology Department Prof. Rifai, Dr. Sunaryo for his criticism, and local informants Mrs. Rosida, Mr. Partono, Mr. Arifin (curator MUBR), etc.

\section{Conflict of interest}

None to declare.

\section{References}

Backer CA and RC Bakhuizen van den Brink, Jr. 1968. Flora of Java. Vol. I, II, III (Spermatophytes Only) N.V.P. Noordhoff. Groningen - The Netherlands.

Batoro J, L Hakim and B Rahardi, 2019. Traditional Knowledge Sacred Area (pedanyangan) in Tengger Tribe of East Java, Indonesia. Advances in life Sciences, 9: 1-6.

Batoro J, 2019. Landscape Traditional Glagah community, Temon District, Kulon Progo Regency Yogyakarta, Indonesia. Journal Transylvanium Review. Volume XXVI, No 42.

Batoro J, Wiyono and I Lutfi, 2019. Perceptions of Sacred Site (Petren) and Plant Diversity in Malang, EastJava, Indonesia. IJBAS-IJENS Vol 19. No. 06. 
Batoro J, S Indriyani and B Yanuwiyadi, 2017. Ethnoecology Local Society in Komplangan Perhutani Bromo Tengger Semeru East Java with Qualitative Approach. Biosaintifika: Journal of Biology \& Biology Education, 9: 41-48.

Batoro J, 2019. Pengantar Umum Keanekaragaman Hayati dan Tumbuhan Beracun. Penerbit MNC Malang, Indonesia.

Cotton CM, 1996. Ethnobotany: Principle and Applications. John Wiley \& Sons. Chichester, New York, Brisbane, Toronto, and Singapore.

Harris JG and MW Harris, 2003. Plant Identification Terminology, An Illustrated Glossary. Spring Lake Publishing, USA.

Hoffman B and T Gallaher, 2007. Importance Indices in Ethnobotany. Ethnobotany Research \& Applications, 5: 201-208.

Horster M, 2010. Religious Landscape and Sacred Ground: Relationships between Space and Cult in the Greek World. Revue de I Histoire des Religions: 435-338.

Proceedings, 2003. The Importance of Sacred Natural Sites for Biodiversity Conservation. Preceedings of the International Workshop Hels in Kunming and Xishuangbanna Biosfer Reserve, Peoples Republik of China, 17-20 Februari 2003, UNESCO.

Samakov A and F Berkes, 2017. Spiritual Commons: Sacred sites as core of community-conserved areas in Kyrgyzstan. International Journal of the Commons, 11: 422-444.

Siswanto D and dan J Batoro, 2019. The sacred plants and their support for conservation, Poncokusumo District, Malang Regency, East Java Indonesia. Plant Archives, 19: 1515-1520.

Sheil D, RK Puri, I Basuki, M van Heiizt, M Wan, N Liswanti, Rukmiyati, MA Sardjono, L Samsoedin, K Sudiyasa, Chrisandini, E Permana, EM Angi, F Gatzweiler, B Johnson and Wijaya, 2004. Exploring biological diversity, environment and local people's perspectives in forest landscapes. Methods for a multidisciplinary landscape assesment. CIFOR, Bogor. Indonesia.

Sudarmadji D, D Darmanto, M Widyastuti and S Lestari, 2016. Springs Management for Sustainability Domestic Water Supply in the South Weast of Merapi Vulcano Slope. Jurnal Manusia dan Lingkungan, 23: 102-110.

Wickramasinghe A, 2003. Adam's Peak Sacred Mountain Forest. Preceedings of the International Workshop Hels in Kunming and Xishuangbanna Biosfer Reserve, Peoples Republik of China, UNESCO. 